\title{
(NIE)ZALEŻNOŚĆ FINANSOWA PAŃSTWA WE WSPÓŁCZESNEJ GOSPODARCE RYNKOWEJ
}

\section{WPROWADZENIE}

Finanse publiczne obejmują zasoby pieniężne państwa. Związane sa one z procesami gromadzenia i podziału środków publicznych znajdujacych się w dyspozycji władz publicznych, a przede wszystkim budżetu państwa. Środki te pochodzą głównie z danin publicznych, majątku publicznego oraz z przychodów zwrotnych, czyli kredytów, pożyczek oraz emisji papierów wartościowych. Zatem przedmiotem finansów publicznych są zjawiska, procesy i instytucje publiczne związane z powstawaniem i rozdysponowaniem pieniężnych środków publicznych zapewniających właściwe funkcjonowanie sektora publicznego. Podmiotami finansów publicznych są przede wszystkim parlament, rząd i jego organy centralne oraz jednostki samorządu terytorialnego.

Niezwykle istotnym pojęciem w szeroko rozumianych finansach jest niezależność (autonomia) finansowa. Niezależność finansowa jest to zdolność do samofinansowania własnej działalności bieżącej i inwestycyjnej z bieżących przychodów oraz posiadanych kapitałów własnych. W przypadku finansów publicznych niezależność finansowa państwa odnosi się do możliwości finansowania przez rząd wszystkich wydatków państwowych wyłącznie z osiaganych dochodów budżetowych. Zatem pełna autonomia finansowa państwa oznacza, że rząd finansuje wydatki budżetowe bez konieczności pożyczania środków przez zaciaganie kredytów bankowych bądź emisję instrumentów dłużnych. Stanem pośrednim w budowaniu pełnej niezależności finansowej państwa jest bezpieczeństwo finansowe. Bezpieczeństwo finansowe państwa to jego zdolność do pozyskania środków pieniężnych w sytuacji, gdy zachodzi taka potrzeba. Jest to stan braku zagrożenia, który daje poczucie pewności funkcjonowania państwa oraz szansę na jego dalszy rozwój. Dlatego też celem niniejszego artykułu jest zbadanie możliwości osiagnięcia przez państwo pełnej autonomii finansowej we współczesnej gospodarce światowej.

Potrzeba osiagnięcia minimalnych standardów życia, tworzenia miejsc pracy, rozbudowy infrastruktury i wspierania wzrostu gospodarczego może sprawiać, że wydatki publiczne przekroczą dochody państwa. Rząd może wówczas wydawać środki finansowe przekraczajace dochody przez dodatkową emisję pieniądza lub zaciąanie kredytu na rynku kapitałowym. Ponieważ emisja pieniądza bezpośrednio powoduje wzrost podaży pieniądza i tym samym 
wzrost inflacji, większość ekonomistów odrzuca tę metodę finansowania deficytu budżetowego. Jeśli chodzi o tę drugą metodę, czyli zaciaganie kredytu, to należy zaznaczyć, że dług publiczny jest generalnie uważany przez ekonomistów za sytuację niepożądaną ${ }^{1}$.

Jak twierdził Smith: „[...] dochody publiczne z jedynego poważnego źródła, którego jeszcze nie zastawiono, są wydawane, zanim wpłyną do skarbu. Podobnie jak nieprzezorny rozrzutnik, któremu naglące potrzeby nie pozwalaja czekać na regularny wpływ dochodów, państwo pożycza stale od swych faktorów i agentów płacąc procenty od użytkowania własnych pieniędzy. Proces narastania ogromnych długów, które przytłaczają prawie wszystkie państwa europejskie i na dłuższą metę doprowadzą je prawdopodobnie do ruiny, przebiegał wszędzie prawie jednakowo. Narody, podobnie jak osoby prywatne, zaczynały na ogół pożyczać opierając się, jakby to można określić, na osobistym kredycie, nie przeznaczając na zabezpieczenie długu specjalnego funduszu, a gdy sposób ten zaczął zawodzić, pożyczały w dalszym ciagu przeznaczając określone fundusze na zabezpieczenie długu"2.

Współcześnie w gospodarkach rynkowych akceptuje się pożyczki rządowe, o ile towarzyszą im zdrowe finanse publiczne. Zasady zdrowych finansów państwa opierają się na założeniu, że należy unikać deficytów strukturalnych. Pierwszym ekonomista, który poparł ten pomysł, był Keynes, w czasach gdy Francja stawiała czoła poważnym deficytom budżetowym. Według Keynesa rząd powinien mieć deficyt w okresie recesji gospodarczej, ale deficyt ten powinien zostać zrównoważony przez nadwyżki budżetowe w okresie wzrostu gospodarczego. Uważa się, że należy unikać trwałego deficytu, ponieważ żaden rząd nie może działać w taki sposób, aby wygenerować oczekiwania, że nigdy nie będzie w stanie wyjśśc z długu ${ }^{3}$.

W kontekście stopniowego rozpowszechniania teorii keynesowskiej uważano, że finansowanie długów jest konieczne, aby zapewnić właściwy poziom zagregowanego popytu, gdy prywatne inwestycje są niewystarczające do absorpcji oszczędności w stosunkowo długim okresie. Tak założył Domar, który starał się udowodnić, że systematyczne zaciąganie pożyczek rządowych skutkuje ciagle rosnacym długiem publicznym, którego obsługa wymaga coraz wyższych podatków. To ostatecznie może negatywnie oddziaływać na gospodarkę, ponieważ uniemożliwia obsługę długu publicznego. Domar wykazał, że stały wskaźnik deficytu budżetowego do PKB zapewnia stabilność zadłużenia $\mathrm{w}$ stosunku do PKB, jak również stabilny udział odsetek w PKB. W konsekwencji stabilny będzie także stosunek podatków potrzebnych do obsługi płatności odsetkowych w relacji $\mathrm{PKB}^{4}$.

\footnotetext{
1 Górniewicz (2012).

2 Smith (2007): 605-650.

${ }^{3}$ Keynes (2003).

4 Domar (1944); Curtaşu (2011): 20-43.
} 


\section{DEFICYT BUDŻETOWY I DLUG PUBLICZNY W GOSPODARCE RYNKOWEJ}

Deficyt budżetowy zazwyczaj jest definiowany jako różnica między ogólnymi wydatkami państwa (włączając odsetki i koszty obsługi długu publicznego) oraz dochodami państwa. Natomiast zgodnie z bardziej rozbudowaną definicją - deficyt budżetowy to różnica między wielkością długu publicznego na koniec danego roku i wielkością długu publicznego na koniec roku poprzedniego. Te dwie definicje są równoważne, jeżeli dług publiczny zdefiniuje się jako wartość wyemitowanych obligacji.

Pojawienie się deficytu budżetowego oznacza, że dług publiczny wzrasta. Ale ponieważ PKB również wzrasta, stosunek długu publicznego do PKB może ulec zmianie lub pozostać na stałym poziomie. Zatem to, czy stosunek długu publicznego do PKB zmienia się, czy też pozostaje na niezmienionym poziomie, zależy od tego, czy stopa wzrostu zadłużenia krajowego jest większa lub mniejsza niż stopa wzrostu PKB. Systematycznie rosnący stosunek zadłużenia krajowego do PKB jest o tyle niebezpieczny dla kraju, że grozi wejściem długu publicznego na ścieżkę niezrównoważonego wzrostu, prowadzącą do niewypłacalności kraju. Nawet jeżeli stosunek długu publicznego do PKB nie wzrasta gwałtownie, to i tak wysoki stosunek zadłużenia do PKB ma poważne i niekorzystne konsekwencje dla kraju, związane chociażby z rosnącym kosztem obsługi długu. Ważne jest więc zrozumienie przyczyn wzrostu wskaźnika długu publicznego do PKB i znalezienie optymalnej wielkości tego wskaźnika dla kraju. W tym celu niezbędne jest odróżnienie standardowego deficytu budżetowego od podstawowego deficytu budżetowego. Podstawowy (pierwotny) deficyt budżetowy jest równy standardowemu deficytowi budżetowemu pomniejszonemu o koszt obsługi długu publicznego ${ }^{5}$.

Zatem standardowy deficyt budżetowy oraz podstawowy deficyt budżetowy można zapisać w formie poniższych wyrażeń, jako:

$$
\begin{gathered}
S B=G+(i \cdot P D)-T \\
P B=G-T
\end{gathered}
$$

gdzie:

$S B$ - standardowy deficyt budżetowy,

$P B$ - podstawy deficyt budżetowy,

$P D$ - dług publiczny,

$G \quad$ - wydatki państwa,

$i \quad$ - stopa oprocentowania długu publicznego,

$T$ - dochody państwa (podatkowe i niepodatkowe).

Zatem na podstawie powyższych wzorów można zapisać wskaźnik długu publicznego do PKB w następującej postaci:

\footnotetext{
${ }^{5}$ Feldstein (2004).
} 


$$
\frac{P D}{G D P}=\left(\frac{G-T}{G D P}\right)+\left(i-\frac{\Delta G D P}{G D P}\right) \cdot\left(\frac{P D}{G D P}\right)
$$

gdzie:

$G D P$ - produkt krajowy brutto.

Zgodnie z powyższym zapisem wskaźnik długu publicznego do PKB to suma wskaźnika podstawowego deficytu budżetowego w stosunku do PKB oraz różnicy między stopa procentową i stopa wzrostu PKB pomnożoną przez stosunek długu publicznego do PKB. Zatem zgodnie z powyższym równaniem stosunek długu publicznego do PKB wzrasta wówczas, gdy w warunkach występowania podstawowego deficytu budżetowego stopa oprocentowania długu publicznego jest większa od stopy wzrostu PKB. W celu zmniejszenia wskaźnika długu publicznego do PKB musi pojawić się nadwyżka w podstawowym bilansie budżetu państwa (większe dochody niż wydatki państwowe) lub PKB musi wzrastać szybciej niż koszt obsługi długu publicznego.

Współcześnie jako główne przyczyny wzrostu deficytu budżetowego i w ślad za tym długu publicznego wskazuje się:

- nieodpowiednią synchronizację między wydatkami budżetowymi i wpływami budżetowymi;

- nadmiernie rozbudowane funkcje państwa;

- brak optymalnej relacji między dochodami podatkowymi nieobniżającymi tempa wzrostu gospodarczego i rozmiarami wydatków państwowych;

- niekorzystne tendencje demograficzne (ujemne saldo przyrostu naturalnego, starzenie się społeczeństw);

- interwencje fiskalne w warunkach recesji gospodarczej;

- nadmierne wydatki publiczne w stosunku do możliwości pozyskiwania dochodów budżetowych.

We współczesnej gospodarce światowej poszczególne kraje charakteryzuja się istotnie zróżnicowanym poziomem długu publicznego w stosunku do PKB. Dotyczy to zarówno krajów wysoko rozwiniętych gospodarczo, jak i krajów rozwijających się i transformujących, przy czym kraje słabiej rozwinięte charakteryzuja się generalnie mniejszym udziałem długu publicznego w PKB, kraje wyżej rozwinięte gospodarczo mają zaś zazwyczaj większy dług publiczny stosunku do PKB.

Tabela 1

Kraje o najmniejszym i największym udziale długu publicznego w PKB w 2016 r. (w \%)

\begin{tabular}{|l|c|l|c|}
\hline \multicolumn{1}{|c|}{ Kraj } & $\begin{array}{c}\text { Udzial długu } \\
\text { publicznego w PKB }\end{array}$ & \multicolumn{1}{c|}{ Kraj } & $\begin{array}{c}\text { Udział długu } \\
\text { publicznego w PKB }\end{array}$ \\
\hline Makao & 0,0 & Japonia & 239,2 \\
\hline Hongkong & 0,1 & Grecja & 181,3 \\
\hline Brunei & 3,1 & Liban & 143,4 \\
\hline
\end{tabular}




\begin{tabular}{|l|c|l|c|}
\hline Afganistan & 8,3 & $\begin{array}{l}\text { Republika Zielonego } \\
\text { Przylądka }\end{array}$ & 133,8 \\
\hline Wyspy Salomona & 9,0 & Włochy & 132,6 \\
\hline Estonia & 9,5 & Portugalia & 130,3 \\
\hline Uzbekistan & 11,6 & Erytrea & 125,5 \\
\hline Arabia Saudyjska & 12,3 & Gambia & 116,1 \\
\hline Botswana & 13,9 & Jamajka & 115,2 \\
\hline Rosja & 17,0 & Mozambik & 115,2 \\
\hline Kuwejt & 18,6 & Singapur & 112,0 \\
\hline Nigeria & 18,6 & Bhutan & 110,2 \\
\hline $\begin{array}{l}\text { Zjednoczone } \\
\text { Emiraty Arabskie }\end{array}$ & 19,3 & Cypr & 107,9 \\
\hline
\end{tabular}

Źródło: Bank Światowy.

Najmniejszym udziałem długu publicznego w PKB charakteryzują się takie kraje, jak: Makao, Hongkong i Brunei, najwyższy zaś udział długu publicznego w PKB występuje w Japonii, Grecji i Libanie.

\section{ZADŁUŻENIE ZAGRANICZNE JAKO ELEMENT DLUGU PUBLICZNEGO}

Międzynarodowa integracja rynków finansowych zwiększa obecnie możliwości finansowania długu państwowego na rynkach zagranicznych. Stąd bardzo często kraje, korzystając z takiej możliwości, zaciągają kredyty, emitują instrumenty finansowe za granica, czego skutkiem jest wzrost zadłużenia zagranicznego. Dług zagraniczny na ogół definiuje się jako całość zadłużenia w walutach obcych, które podmioty krajowe (rząd, banki komercyjne, przedsiębiorstwa, osoby prywatne) zaciagnęeły za granica. Stąd dług zagraniczny może występować w postaci długu państwowego i wówczas jest częścią długu publicznego albo może być to dług, który zaciagają podmioty prywatne. Dług zagraniczny występuje w formie kredytów zagranicznych, jak również $\mathrm{w}$ formie posiadanych przez podmioty zagraniczne skarbowych papierów wartościowych lub obligacji przedsiębiorstw ${ }^{6}$ (por. tab. 1).

W warunkach postępujących procesów liberalizacji międzynarodowych przepływów kapitału oszczędności poszukują najefektywniejszego wykorzystania bez względu na lokalizację. Wierzyciele zagraniczni są gotowi pożyczać fundusze krajowym podmiotom, gdyż rozdzielając swoje oszczędności pomiędzy szerszą gamę aktywów finansowych na wiele państw, dywersyfikują w ten sposób ryzyko wahań dochodów ze swoich inwestycji ${ }^{7}$.

\footnotetext{
${ }^{6}$ Kosztowniak (2017).

7 Sachs (2002).
} 
Tabela 2

Ogólna klasyfikacja długu zagranicznego

\begin{tabular}{|l|l|}
\hline \multicolumn{1}{|c|}{ Kryterium podziału } & \multicolumn{1}{c|}{ Rodzaje długu zagranicznego } \\
\hline Termin wygaśnięcia & $\begin{array}{l}\text { - krótkoterminowy (poniżej 1 roku) } \\
- \text { długoterminowy (powyżej 1 roku) }\end{array}$ \\
\hline Charakter przepływów & $\begin{array}{l}\text { - zobowiázania } \\
\text { - płatności odsetkowe } \\
\text { - amortyzacja } \\
\text { - restrukturyzacja }\end{array}$ \\
\hline Rodzaj dłużnika & $\begin{array}{l}\text { - publiczny } \\
\text { - prywatny }\end{array}$ \\
\hline Rodzaj wierzyciela & $\begin{array}{l}\text { - oficjalny } \\
\text { - prywatny }\end{array}$ \\
\hline
\end{tabular}

Źródło: opracowanie własne na podstawie Adepoju, Salau, Obayelu (2007).

Oszczędności zagraniczne sa jednym ze źródeł finansowania wewnętrznej akumulacji w każdej gospodarce. W szczególności kraje rozwijające się charakteryzują się niewystarczającą wewnętrzną akumulacją kapitału ze względu na występowanie w nich specyficznego błędnego koła wynikającego z niskiej wydajności czynników produkcji, niskich dochodów oraz niskiego poziomu oszczędności. W związku z tym taka sytuacja wymaga technicznego i finansowego wsparcia krajów wysoko rozwiniętych gospodarczo w celu wypełnienia luki w zasobach kapitału.

Rosnące oszczędności oraz inwestycje w gospodarce prowadzą do wzrostu gospodarczego ${ }^{9}$. Jednakże należy zaznaczyć, że wzrost gospodarczy nie wystapi dopóty, dopóki zasoby kapitałowe nie przekroczą określonego poziomu. Jeśli wzrastają zasoby kapitału, inwestycje i produkcja, to poziom oszczędności również wzrasta. Po przekroczeniu określonego poziomu wzrost zarówno zasobów kapitału i oszczędności będzie wystarczający do wywołania wzrostu gospodarczego. Tyle tylko, że oszczędności same nie są wystarczającym warunkiem rozpoczęcia inwestycji. Dany rynek musi spełnić dodatkowe warunki. Między innymi chodzi o to, by stopa zwrotu z realizowanych inwestycji była większa niż stopa procentowa, według której kapitał jest pozyskiwany z rynku $\mathrm{w}$ celu sfinansowania wspomnianych inwestycji. Warunek ten najpełniej będzie spełniony w sytuacji występowania niskiej inflacji i niskich rynkowych stóp procentowych. Autorzy teorii tzw. podwójnej luki (dual gap theory) twierdza, że inwestycje są funkcją oszczędności i w związku z tym w krajach rozwijających się poziom krajowych oszczędności jest niewystarczający do sfinansowania niezbędnych inwestycji zapewniających wzrost gospodarczy ${ }^{10}$. W takiej sytuacji należy korzystać z oszczędności innych krajów, które je maja.

\footnotetext{
8 Adepoju, Salau, Obayelu (2007).

9 Hunt (2007).

10 Sachs (2002).
} 
Z drugiej strony zbyt wysokie rozmiary zadłużenia zagranicznego moga doprowadzić do spowolnienia rozwoju gospodarczego przez tzw. nawis zadłużenia (debt overhang) ${ }^{11}$. Nawis zadłużenia występuje w sytuacji, w której rozmiary zadłużenia zagranicznego kraju przekraczają jego zdolność do spłaty długu w długim okresie. W tej sytuacji stosunkowo duże rozmiary zadłużenia zagranicznego zniechęcaja przedsiębiorstwa do podejmowania inwestycji, ponieważ potencjalni inwestorzy przewidują wzrost obciążeń podatkowych w przyszłości w celu spłaty długu zagranicznego przez państwo. Dodatkowo rosnace rozmiary zadłużenia zagranicznego mogą wywoływać wśród uczestników rynku wrażenie pogłębiającej się niestabilności makroekonomicznej w kraju, która jest związana między innymi z rosnącym deficytem budżetowym, deprecjacją waluty krajowej czy przewidywaną inflacją w kraju. Opisaną powyżej zależność można przedstawić poniżej za pomocą tzw. zadłużeniowej krzywej Laffera (Laffer debt curve) (por. wykres 1).

Wykres 1

Zadłużeniowa krzywa Laffera

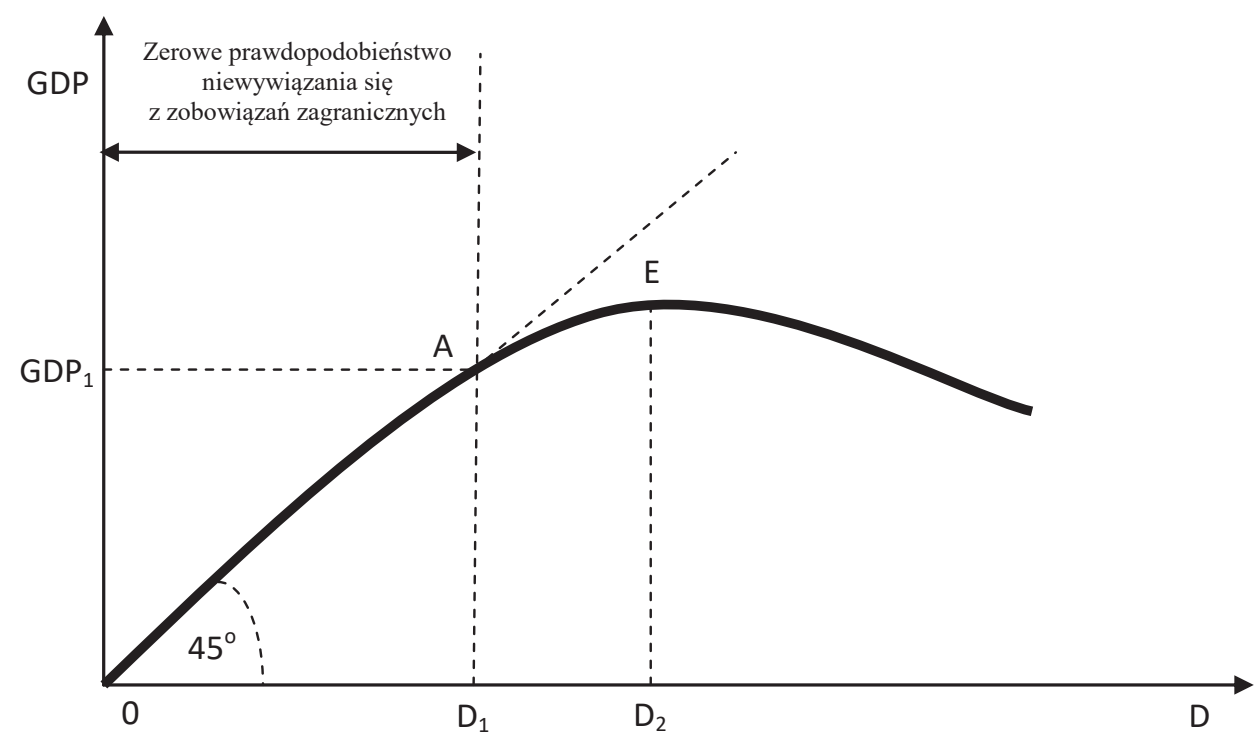

Źródło: Krugman (1989).

Zadłużeniowa krzywa Laffera przedstawia zależność między wzrostem gospodarczym oraz skumulowanym długiem zagranicznym kraju. Mianowicie w miarę wzrostu rozmiarów długu zagranicznego wzrasta również produkt krajowy brutto kraju, lecz jedynie do pewnego poziomu długu równego $D_{2}$, po którego przekroczeniu oddziaływanie długu zagranicznego na wzrost gospo-

11 Were (2001). 
darczy zaczyna być negatywne. Ponadto należy zauważyć, że jeśli dług zagraniczny przekracza bezpieczny rozmiar (poziom $D_{1}$ ), przy którym wzrasta ryzyko niewywiązania się kraju z zobowiązań zagranicznych, to dynamika wzrostu gospodarczego jest coraz niższa. Zatem optymalnym poziomem długu zagranicznego kraju jest poziom $D_{2}$, przy którym wartości PKB są najwyższe. $\operatorname{staci}^{12}$ :

Równanie produktu krajowego brutto można przedstawić w poniższej po-

$$
Y=C+S=C+I+(X-M)
$$

gdzie:

$Y$ - produkcja krajowa,

$C-$ konsumpcja,

$S$ - krajowe oszczędności,

$I \quad$ - inwestycje,

$X$ - eksport,

$M$ - import.

W tym przypadku inwestycje obejmuja zarówno prywatne wydatki inwestycyjne oraz publiczne wydatki inwestycyjne:

$$
I=I_{P}+I_{G}
$$

gdzie:

$I_{P} \quad-$ inwestycje prywatne,

$I_{G}=G-$ wydatki rządowe.

Z równań (4) i (5) wynika, że jeśli produkcja krajowa jest równa konsumpcji i krajowym oszczędnościom, to krajowy popyt inwestycyjny jest równy sumie krajowych oszczędności oraz importowi netto, który jest finansowany przez zagraniczne pożyczki netto:

$$
I=S+(M-X)
$$

gdzie:

$(M-X)-$ import netto (zagraniczne pożyczki netto).

Natomiast w poniższym modelu pożyczki zagraniczne są określane mianem transferów podstawowych (basic transfers - BT) i równe są różnicy między napływem kapitału netto (napływy kapitału brutto pomniejszone o amortyzację) a płatnościami odsetkowymi od długu zagranicznego ${ }^{13}$ :

$$
B T=d D-r D=D(d-r)
$$

12 Root (1978).

13 Chenery, Strout (1966). 
gdzie:

$B T$ - transfery podstawowe,

$D$ - całkowity dług zagraniczny,

$d$ - stopa wzrostu długu zagranicznego,

$r$ - średnia, roczna stopa procentowa,

$d D$ - napływ kapitału netto,

$r D$ - całkowite, roczne płatności odsetkowe.

Zgodnie z modelem (7) transfery podstawowe oznaczaja zyski dla kraju, jeśli $d>r$, straty zaś, gdy $d<r$. Ogólnie rzecz biorąc, jeśli napływ pożyczek zagranicznych wiąże się ze wzrostem produktywności, stopa zwrotu przekracza średni poziom stopy procentowej w kraju, a transfery podstawowe są dodatnie, to wzrost długu zagranicznego nie oddziałuje negatywnie na wzrost gospodarczy w danym kraju w długim okresie. Biorąc pod uwagę zmiany długu zagranicznego w czasie, sytuację tę można przedstawić w następującej postaci:

$$
\left(D_{t}-D_{t-1}\right)=Y_{t}-r D_{t}-C_{t}-I_{t}-G_{t}
$$

gdzie:

$$
\begin{array}{ll}
\left(D_{t}-D_{t-1}\right) & - \text { zmiany netto długu zagranicznego w okresie } t-1 \text { do } t \\
t & - \text { okres analizy. }
\end{array}
$$

Nawiąując do równania (8), można zauważyć, że rozmiary długu zagranicznego mogą być zmniejszone w wyniku wzrostu krajowej produkcji, spadku krajowej konsumpcji, krajowych inwestycji i wydatków rządowych. Z drugiej strony, jeśli dług zagraniczny osiagnie tak duże rozmiary, że suma krajowej produkcji, konsumpcji, inwestycji i wydatków rządowych będzie mniejsza od transferów podstawowych, wówczas sytuacja ta doprowadzi do kryzysu zadłużeniowego.

Kryzys zadłużeniowy, zwany także kryzysem zadłużenia zagranicznego, oznacza sytuację, w której dany kraj nie jest w stanie obsługiwać swego zadłużenia zagranicznego. Sytuacja ta może mieć charakter przejściowy, wówczas mówi się o kryzysie płynności (liquidity crisis), lub może mieć charakter trwały, wówczas określa się go mianem kryzysu niewypłacalności (solvency crisis).

We współczesnej gospodarce światowej nieco inaczej niż w przypadku długu publicznego wygląda sytuacja w odniesieniu do zadłużenia zagranicznego. Mianowicie kraje słabiej rozwinięte gospodarczo (rozwijajace się i transformujące) odznaczają się zarówno bardzo niskim, jak również bardzo wysokim udziałem długu zagranicznego w PKB. Z kolei w krajach wysoko rozwiniętych gospodarczo udział zadłużenia zagranicznego w PKB jest na względnie stabilnym poziomie. Najmniejszym udziałem długu zagranicznego w PKB charakteryzują się takie kraje, jak: Turkmenistan, Iran i Algieria, najwyższy zaś udział długu zagranicznego w PKB występuje w Serbii, Kazachstanie i Mołdawii. 
Tabela 3

Kraje o najmniejszym i największym udziale długu zagranicznego w PKB w 2016 r. (w \%)

\begin{tabular}{|l|c|l|c|}
\hline \multicolumn{1}{|c|}{ Kraj } & $\begin{array}{c}\text { Udział dlugu } \\
\text { zagranicznego w PKB }\end{array}$ & \multicolumn{1}{c|}{ Kraj } & $\begin{array}{c}\text { Udział długu } \\
\text { zagranicznego w PKB }\end{array}$ \\
\hline Turkmenistan & 1,1 & Mongolia & 201,7 \\
\hline Iran & 1,6 & Panama & 180,3 \\
\hline Algieria & 2,9 & Ukraina & 137,4 \\
\hline Nigeria & 6,2 & Mauritius & 128,5 \\
\hline Suazi & 10,1 & Kirgistan & 118,6 \\
\hline Afganistan & 12,6 & Gruzja & 109,4 \\
\hline Chiny & 13,1 & Bhutan & 105,8 \\
\hline Egipt & 14,3 & Jamajka & 103,1 \\
\hline Botswana & 15,1 & Laos & 99,6 \\
\hline Czad & 15,3 & $\begin{array}{l}\text { Republika } \\
\text { Zielonego Przylądka }\end{array}$ & 97,7 \\
\hline Kongo & 16,8 & Mołdawia & 91,1 \\
\hline Wyspy Salomona & 18,0 & Kazachstan & 89,3 \\
\hline Bangladesz & 18,6 & Serbia & 88,8 \\
\hline
\end{tabular}

Źródło: Bank Światowy.

\section{DLUG PUBLICZNY A WZROST GOSPODARCZY}

Niektórzy ekonomiści, tacy jak Modigliani, wskazuja, że zwiększenie długu publicznego zawsze przyczynia się do spadku tempa wzrostu gospodarczego $^{14}$. Z kolei Patillo, Romer i Weil stwierdzili, że niski poziom długu publicznego wpływa dodatnio na wzrost gospodarczy, wysokie rozmiary zadłużenia zaś oddziałują negatywnie na tempo wzrostu gospodarczego kraju ${ }^{15}$.

Schclarek, analizujac łącznie 59 krajów rozwijających się i 24 kraje wysoko rozwinięte gospodarczo, stwierdził, że w przypadku tych pierwszych zawsze występuje ujemny i istotny związek między całkowitym zadłużeniem państwa i wzrostem gospodarczym. Z kolei w odniesieniu do krajów wysoko rozwiniętych gospodarczo nie znalazł on istotnej zależności między długiem publicznym i wzrostem gospodarczym ${ }^{16}$.

Z kolei Ferreira, analizując związek między wzrostem gospodarczym i długiem publicznym, potwierdził występowanie związku między wzrostem gospo-

14 Modigliani (1961).

15 Patillo, Romer, Weil (2004).

16 Schclarek (2005). 
darczym per capita i długiem publicznym w stosunku do PKB w krajach członkowskich Organizacji Współpracy Gospodarczej i Rozwoju (OECD) w okresie 1988-2001. Ponadto stwierdził, że zależność ta jest zawsze dwukierunkowa17: wzrost gospodarczy prowadzi do wzrostu oszczędności w kraju, a wzrost krajowych oszczędności prowadzi do wzrostu dochodu narodowego na mieszkańca.

Keho badał związek przyczynowo-skutkowy między deficytem budżetowym i wzrostem gospodarczym w siedmiu wybranych krajach Afryki Zachodniej w okresie 1980-2005. Uzyskane wyniki badań okazały się niejednoznaczne. W przypadku trzech krajów nie stwierdzono występowania związku przyczynowo-skutkowego między deficytem budżetowym i wzrostem gospodarczym. Zatem deficyt budżetowy w tym przypadku nie wpływał w żaden sposób na wzrost gospodarczy. Wyniki badań ujawniły również w przypadku trzech kolejnych krajów występowanie dwukierunkowej, ujemnej zależności między deficytem budżetowym i wzrostem gospodarczym ${ }^{18}$. Oznaczało to negatywne oddziaływanie rosnącego deficytu budżetowego na wzrost gospodarczy w kraju i negatywny wpływ wzrostu gospodarczego na rozmiary deficytu budżetowego w kraju.

Ponadto wyniki badań empirycznych przeprowadzonych przez Kumar i Woo na grupie krajów obejmujaccej zarówno gospodarki wysoko rozwinięte, jak również rozwijające się wskazują na występowanie odwrotnej zależności między początkowym długiem publicznym i wzrostem gospodarczym w okresie 1970-2007. Rezultaty ich analiz potwierdzaja, że wzrostowi wskaźnika długu publicznego do PKB o 10 punktów procentowych towarzyszył spadek realnego PKB per capita o około 0,2 punktu procentowego w ciagu jednego roku ${ }^{19}$.

Jednocześnie należy podkreślić, że wiele analiz empirycznych przeprowadzonych w ciagu ostatnich kilkunastu lat wskazuje na występowanie nieliniowej zależności między długiem publicznym i wzrostem gospodarczym: wyniki tych badań wskazuja, że dług publiczny pozytywnie wpływa na wzrost gospodarczy, lecz jedynie do pewnego poziomu długu, ale po jego przekroczeniu jest już negatywny ${ }^{20}$.

Podobne analizy prowadzili Smyth i Hsing, którzy badali wpływ długu publicznego na wzrost gospodarczy w USA w latach osiemdziesiatych i dziewięćdziesiątych XX w. Szacowali optymalny poziom długu publicznego dla gospodarki amerykańskiej, tzn. taki poziom długu publicznego, który maksymalizuje wzrost gospodarczy. Wyniki tych badań wskazywały, że optymalny poziom długu publicznego w stosunku do PKB dla gospodarki USA wynosił w badanym okresie $38,4 \%{ }^{21}$. Obecne potrzeby pożyczkowe USA w liczbach absolutnych są ogromne, ze względu na fakt, że jest to duża gospodarka. Jednocześnie potrzeby te rosną szybciej niż amerykański PKB, co w przyszłości może spowodować wiele negatywnych konsekwencji makroekonomicznych.

\footnotetext{
17 Ferreira (2009).

18 Keho (2010).

19 Kumar, Woo (2010).

20 Moore, Chrystol (2008).

21 Smyth, Hsing (1995).
} 
Do podobnych wniosków o występowaniu nieliniowej zależności między długiem publicznym i wzrostem gospodarczym doszli również Elbadawi, Ndulu i Ndung'u, analizując zależności między długiem publicznym i PKB w 26 krajach Afryki subsaharyjskiej w okresie 1980-1994. Wykazali oni bowiem, że dług publiczny pozytywnie oddziaływał na wzrost gospodarczy w tych krajach, ale jedynie do poziomu 97\% $\mathrm{PKB}^{22}$. Z kolei Pattillo, Poirson, Ricci, badając 93 kraje rozwijające się w okresie 1972-1998, uzyskali wyniki wskazujące na pozytywny wpływ długu publicznego na wzrost gospodarczy jedynie do poziomu 35-40\% $\mathrm{PKB}^{23}$.

Natomiast Reinhart i Rogoff, analizujacc 44 kraje wysoko rozwinięte gospodarczo i rozwijajacce się w okresie ostatnich 200 lat, doszli do wniosku, że wysokiemu poziomowi długu publicznego w stosunku do PKB (powyżej 90\%) towarzyszył niższy poziom wzrostu gospodarczego w krajach zarówno rozwiniętych gospodarczo, jak i rozwijających się. Ponadto w przypadku krajów rozwijających się stosunkowo wysoki poziom długu zagranicznego w stosunku do PKB (powyżej 60\%) negatywnie oddziaływał na wzrost gospodarczy ${ }^{24}$.

Cecchetti, Mohanty i Zampolli badali zależność między długiem publicznym i wzrostem gospodarczym w 18 krajach członkowskich OECD w okresie 1980-2010. Stwierdzili, że dług publiczny zaczynał obniżać wzrost gospodarczy wtedy, gdy przekraczał próg około $85 \% \mathrm{PKB}^{25}$.

Ahlborn i Schweickert twierdza, że to różne systemy gospodarcze krajów przy porównywalnych poziomach długu publicznego stanowią główne źródło heterogeniczności w odniesieniu do oddziaływania długu publicznego na wzrost gospodarczy. Otóż w krajach kontynentalnych (tzw. kraje rdzenia Unii Europejskiej) odnotowuje się większy wpływ redukcji długu publicznego na wzrost gospodarczy niż w krajach liberalnych. W gospodarkach liberalnych (anglosaskich) dług publiczny wywiera neutralny lub pozytywny wpływ na wzrost gospodarczy. Z kolei w krajach nordyckich (skandynawskich) zachodzi nieliniowy związek między długiem publicznym i wzrostem gospodarczym, przy czym negatywne skutki długu publicznego ujawniaja się przy poziomie długu zbliżonym do $60 \% \mathrm{PKB}^{26}$.

\section{DŁUG ZAGRANICZNY A WZROST GOSPODARCZY}

Perasso, analizując dane statystyczne dotyczące 20 najbardziej zadłużonych krajów świata o średnim poziomie dochodu, zbadał związek między wzrostem gospodarczym i zadłużeniem zagranicznym w okresie 1982-1989. Wyniki badań pokazały, że odpowiednio prowadzona polityka gospodarcza w kraju $\mathrm{w}$ większym stopniu oddziaływała na wzrost inwestycji i wzrost gospodarczy

\footnotetext{
22 Elbadaw, Ndulu, Ndung'u (1997).

23 Pattillo, Poirson, Ricci (2004).

24 Reinhart, Rogoff (2010).

25 Cecchetti, Mohanty, Zampolli (2011).

26 Ahlborn, Schweickert (2015).
} 
w wysoce zadłużonych krajach niż zmniejszenie zobowiązań z tytułu obsługi zadłużenia zagranicznego ${ }^{27}$.

Natomiast Cunningham badał związki między obciążeniem długiem zagranicznym i wzrostem gospodarczym w 16 krajach w okresie 1971-2007. Badania ujawniły, że wzrost obciążenia długiem zagranicznym miał negatywny wpływ na ich wzrost gospodarczy ${ }^{28}$.

Z kolei Cohen analizował relację między zadłużeniem zewnętrznym i inwestycjami w krajach rozwijających się w latach osiemdziesiątych XX w. Badania pokazały, że występował stosunkowo niewielki wpływ rozmiarów zadłużenia zagranicznego na rozmiary inwestycji w tych krajach. Badania ujawniły także występowanie efektu wypierania inwestycji krajowych (crowding out effect) przez wydatki ponoszone na obsługę długu zagranicznego ${ }^{29}$.

Natomiast Metwally i Tamaschke, wykorzystując podwójną i zwykłą metodę najmniejszych kwadratów, analizowali relacje między kosztami obsługi zadłużenia zagranicznego, napływem kapitału zagranicznego i wzrostem gospodarczym w Algierii, Maroku i Egipcie w latach 1972-2002. Wyniki badań pokazały, że napływ kapitału zagranicznego miał istotny wpływ na stosunek długu zagranicznego do wzrostu gospodarczego ${ }^{30}$.

Chowdhury badał relację między zadłużeniem zagranicznym i wzrostem gospodarczym w Bangladeszu, Indonezji, Malezji, Filipinach, Korei Południowej, Sri Lance i Tajlandii w okresie 1988-1970. Wyniki badań ujawniły niekorzystny wpływ zadłużenia zagranicznego na poziom kursu walutowego, jednakże nie ujawniono oddziaływania zadłużenia zewnętrznego na tempo wzrostu PKB w tych krajach ${ }^{31}$.

Fosu badał związek między wzrostem gospodarczym i zadłużeniem zagranicznym w krajach Afryki subsaharyjskiej w okresie 1986-1970 i wykazał, że kraje wysoko zadłużone odnotowywały średniorocznie jednoprocentowy spadek tempa wzrostu PKB w wyniku wysokich rozmiarów długu zagranicznego ${ }^{32}$.

Deshpande analizował relację między zadłużeniem zewnętrznym i rozmiarami inwestycji w 13 wysoce zadłużonych krajach w latach 1991-1971 za pomocą zwykłej metody najmniejszych kwadratów. Badania potwierdziły występowanie $\mathrm{w}$ nich ujemnej relacji między rozmiarami zadłużenia zewnętrznego $\mathrm{i}$ inwestycji ${ }^{33}$.

Karagol badał krótkookresowe i długookresowe związki między wzrostem gospodarczym i wydatkami z tytułu obsługi długu zagranicznego w Turcji w okresie 1956-1996 przy wykorzystaniu technik kointegracji i modelu standardowej funkcji produkcji. Rezultaty badań ujawniły występowanie negatywnego wpływu wydatków z tytułu obsługi zadłużenia zagranicznego na wzrost

\footnotetext{
27 Perasso (1992).

${ }^{28}$ Cunningham (1993).

${ }^{29}$ Cohen (1993).

${ }^{30}$ Metwally, Tamaschke (1994).

31 Chowdhury (1994).

32 Fosu (1996).

33 Deshpande (1997).
} 
gospodarczy w długim okresie. Zależność tę potwierdziły również wyniki przeprowadzonych testów przyczynowości Grangera ${ }^{34}$.

Clements, Bhattarcharya i Nguyen potwierdzili występowanie negatywnego wpływu długu zagranicznego na wzrost gospodarczy w wyniku występowania efektu wypierania inwestycji krajowych przez inwestycje zagraniczne. Sytuacja ta wynikała z faktu, że wysokie koszty obsługi długu zagranicznego przyczyniały się do spadku posiadanych zasobów i inwestycji publicznych w kraju ${ }^{35}$.

Folorunso i Felix badali wpływ długu zagranicznego oraz kosztów związanych z jego obsługa na wzrost gospodarczy w Nigerii oraz krajach Afryki Południowej w latach 1980-2007. Bazując na neoklasycznym modelu wzrostu gospodarczego oraz wykorzystując klasyczną i podwójna metodę najmniejszych kwadratów, potwierdzili negatywne oddziaływanie długu zagranicznego i kosztów jego obsługi na wzrost gospodarczy we wszystkich z analizowanych krajów. Co więcej, ujawnili, że ujemny wpływ długu zagranicznego na wzrost gospodarczy w Nigerii wystapił dopiero wtedy, gdy rozmiary tego długu przekraczały określony poziom ${ }^{36}$.

Natomiast badania przeprowadzone przez Atique i Malik ujawniły występowanie ujemnej zależności między krajowym długiem państwowym i wzrostem gospodarczym oraz podobną zależność między zadłużeniem zagranicznym i wzrostem gospodarczym. Co więcej, okazało się, że rosnący dług zagraniczny spowalnia wzrost gospodarczy w znacznie większym stopniu niż dług krajowy ${ }^{37}$.

\section{ZAKOŃCZENIE}

Zgodnie z definicja przytoczona we wstępie artykułu pełna niezależność finansowa państwa to możliwość finansowania przez rząd wszystkich wydatków państwowych wyłącznie z osiaganych dochodów budżetowych. We współczesnej gospodarce światowej w zasadzie gospodarka żadnego z krajów nie finansuje w pełni swoich wydatków budżetowych wyłącznie z osiaganych dochodów budżetowych, czyli bez konieczności pożyczania środków finansowych. W praktyce okazuje się, że współcześnie w krajach występuje większy lub mniejszy dług publiczny, co oznacza, że państwa finansuja swój rozwój, pożyczając środki w kraju i za granica.

Wysoki dług publiczny może powodować poważne problemy. Należy w tym miejscu zaznaczyć, że sam dług publiczny nie musi być szkodliwy dla gospodarki. W zależności od sytuacji rosnący dług publiczny może zwiększyć lub zmniejszyć dobrobyt. Bezwzględna kwota długu publicznego nie ma w tym przypadku większego znaczenia, lecz ważny jest udział długu publicz-

\footnotetext{
${ }^{34}$ Karagol (2002).

35 Clements, Bhattarcharya, Nguyen (2003).

36 Folorunso, Felix (2008).

37 Atique, Malik (2012).
} 
nego w stosunku do produktu krajowego brutto. Zatem istotna kwestia jest nie tyle utrzymanie pełnej niezależności finansowej państwa, ile zagwarantowanie bezpieczeństwa finansowego państwa, czyli utrzymanie zdolności do pozyskania przez państwo środków pieniężnych w sytuacji, gdy zachodzi taka potrzeba.

Jeśli chodzi o wyniki badań empirycznych dotyczących wpływu długu publicznego (w tym zagranicznego) na wzrost gospodarczy, to należy stwierdzić, że w większości przypadków potwierdzono występowanie negatywnego wpływu wysokiego zadłużenia publicznego na wzrost gospodarczy, podczas gdy jedynie w niewielkiej części przeprowadzonych analiz nie ujawniono żadnych istotnych relacji przyczynowo-skutkowych między wzrostem gospodarczym i długiem państwowym.

Jednocześnie należy stwierdzić, że dług rządowy nie może być porównywany z długiem prywatnym. Dotyczy to przede wszystkim przyszłych obciążeń z tytułu długu publicznego, które nie są tożsame z obciążeniem podatkowym przyszłych pokoleń w celu finansowania amortyzacji i odsetek. Przyszły ciężar długu zależy w szczególności od stopnia, w jakim prywatne inwestycje sa wypierane przez wydatki rządowe w wyniku zaciagania pożyczek w sektorze publicznym, i od wielkości inwestycji publicznych finansowanych z pożyczek.

Biorąc pod uwagę różne przyczyny i wzajemne zależności makroekonomiczne, można stwierdzić, że nie ma konkretnego odsetka, jeśli chodzi o relację długu publicznego do PKB, który można zdefiniować ex ante jako próg, powyżej którego rządy powinny spodziewać się pogorszenia warunków uzyskania kredytów na rynkach kapitałowych i do pogorszenia sytuacji w całej gospodarce. Oznacza to, że wysokie pożyczki w walucie lokalnej są na przykład dużo mniej niebezpieczne niż zadłużenie wobec nierezydentów w walucie obcej.

Zatem celem polityki fiskalnej powinno być zapewnienie zrównoważonego długu publicznego, a nie zmniejszenie go do zera lub do wcześniej ustalonego bezwzględnego poziomu. Na zrównoważony dług wpływają różne czynniki. Jednym z nich jest wzrost gospodarczy. Wysoki wzrost gospodarczy automatycznie zmniejsza stosunek długu publicznego do PKB, generując wyższe dochody z podatków i prowadząc do niższych wydatków socjalnych, przyczynia się do niższych deficytów, a nawet nadwyżek rządowych. Ponadto jeśli realna stopa procentowa od długu publicznego jest trwale niższa niż realna stopa wzrostu gospodarczego, to zadłużenie jest zrównoważone. Z kolei jeśli realna stopa procentowa jest wyższa niż realna stopa wzrostu gospodarczego w długim okresie, to bilans pierwotny, czyli różnica pomiędzy bieżącymi dochodami publicznymi a wydatkami publicznymi pomniejszone o odsetki od istniejacego długu publicznego, musi wykazywać nadwyżkę. W przeciwnym razie udział płatności odsetkowych w budżecie publicznym zwiększy się i ograniczy zakres sektora publicznego.

Piotr Misztal

Uniwersytet Jana Kochanowskiego w Kielcach

pmisztal@ujk.edu.pl

https://orcid.org./0000-0003-2609-3439 
Adepoju, A.A., Salau, A.S., Obayelu, A.E. (2007). The effects of external debt management on sustainable economic growth and development: lessons from Nigeria. Munich Personal RePEC Achieve Paper 2147: 1-31.

Ahlborn, M., Schweickert, R. (2015). Public debt and economic growth - economic systems matter. PFH Research Paper 02: 1-28.

Atique, R., Malik, K. (2012). Impact of domestic and external debt on the economic growth of Pakistan. World Applied Sciences Journal 20(1): 120-129.

Cecchetti, S., Mohanty, M.S., Zampolli, F. (2011). The real effects of debt. Bank For International Settlements Working Papers 352: 1-34.

Chenery, H.B., Strout A. (1966). Foreign assistance and economic development. American Economic Review 56: 679-733.

Chowdhury, K. (1994). A structural analysis of external debt and economic growth: some evidence from selected countries in Asia and the Pacific. Applied Economics 26: 1121-1131.

Clements, B., Bhattarcharya, R., Nguyen, T.Q. (2003). External debt, public investment, and growth in low-income countries. International Monetary Fund Working Paper 03/249: 1-24.

Cohen, D. (1993). Low investment and large LCD debt in the 1980s. American Economic Review 83(3): 437-449.

Cunningham, R.T. (1993). The effects of debt burden on economic growth in heavily indebted nations. Journal of Economic Development 18(1): 115-125.

Curtaşu, A.R. (2011). How to assess public debt sustainability: empirical evidence for the advanced European countries. Romanian Journal of Fiscal Policy 2(2): 20-43.

Deshpande, A. (1997). The debt overhang and the disincentive to invest. Journal of Development Economics 52(1): 169-187.

Elbadaw, I., Ndulu, B., Ndung'u, N. (1997). Debt overhang and economic growth in Sub-Saharan Africa, [w:] Z. Iqbal, R. Kanbur (eds.), External Finance for Low-Income Countries. Washington: International Monetary Fund: 1-257.

Feldstein, M. (2004). Budget deficits and national debt. K. Jha Memorial Lecture at the Reserve Bank of India in Mumbai 12: 1-5.

Ferreira, C. (2009). Public debt and economic growth: a granger causality panel data approach. Technical University of Lisbon Working Papers 24: 1-17.

Folorunso, S.A., Felix, O.A. (2008). The impact of external debt on economic growth: a comparative study of Nigeria and South Africa. Journal of Sustainable Development in Africa 10(3): $234-264$.

Fosu, A.K. (1996). The impact of external debt on economic growth in Sub-Saharan Africa. Journal of Economic Development 12(1): 93-118.

Górniewicz, G. (2012). Dług publiczny. Historia, teraźniejszość, przyczyny i perspektywy. Bydgoszcz: Oficyna Wydawnicza Mirosław Wrocławski: 1-261.

Hunt, S.D. (2007). Economic growth: should policy focus on investment or dynamic competition? European Business Review 19(4): 274-314.

Karagol, E. (2002). The causality analysis of external debt service and GNP: the case of Turkey. Central Bank Review 2(1): 39-64.

Keho, Y., (2010). Budget deficits and economic growth: causality evidence and policy implications for WAEMU countries. European Journal of Economics, Finance and Administrative Sciences 18: 99-104.

Keynes, J.M. (2003). Ogólna teoria zatrudnienia procentu i pieniądza. Tłum. M. Kalecki, S. Rączkowski. Warszawa: PWN.

Kosztowniak, A. (2017). Zadłużenie zagraniczne a rozwój gospodarczy. Warszawa: CEDEWU.

Kumar M.S., Woo, J. (2010). Public debt and growth. IMF Working Paper 174: 1-46.

Metwally, M.M., Tamaschke, R. (1994). The interaction among foreign debt, capital flows, and growth: case studies. Journal of Policy Modelling 16(6): 597-608.

Modigliani, F. (1961). Long-run implications of alternative fiscal policies and the burden of the national debt. Economic Journal 71(284): 730-755.

Moore, W., Chrystol, T. (2008). A meta-analysis of the relationship between debt and growth. Munich Personal RePEc Archive Paper 21474: 1-23.

Pattillo, C., Poirson, H., Ricci L. (2004). What are the channels through which external debt affects growth? IMF Working Paper 15: 1-34. 
Perasso, G. (1992). Debt Reduction versus Appropriate Domestic Policies. Kyklos 45(4): 457-467. Reinhart, C.M., Rogoff, K.S. (2010). Growth in a time of debt. NBER Working Paper 15639: 1-26. Root, R.F. (1978). Constraints on Domestic Investment Faced by Developing Countries. International Trade and Investment. Ohio: South-Western Publishing.

Sachs, J.D. (2002). Resolving the debt crisis of low-income countries. Brooking Papers on Economic Activity 33(1): 257-286.

Schclarek, A. (2005). Debt and economic growth in developing and industrial countries. Lund University Working Papers 34: 1-39.

Smith, A. (2007). Badania nad natura i przyczynami bogactwa narodów. Tłum. A. Prejbisz, B. Jasińska. Warszawa: PWN.

Smyth, D.J., Hsing, Y. (1995). In search of an optimal debt ratio for economic growth. Contemporary Economic Policy 13(4): 51-59.

Were, M. (2001). The impact of external debt on economic growth in Kenya: an empirical assessment. World Institute for Development Economics Research Discussion Paper 116: 1-21.

\section{FINANCIAL (IN)DEPENDENCE IN THE CONTEMPORARY MARKET ECONOMY}

\section{Summary}

State financial independence refers to the ability of the government to finance all state expenditure solely from the budgetary revenue attained. Thus, the full financial autonomy of the state means that the government finances the budgetary expenditures without having to borrow money. Therefore, the aim of this article is to examine the possibility for states to achieve full financial autonomy in the contemporary world economy. The results of the studies show that almost all countries now have a large or small public debt, which means that countries finance their development by borrowing money at home and abroad. The important issue seems to be not so much to maintain the full financial independence of the State as to guarantee the financial security of the state (that is, to maintain the ability of the state to raise money when necessary).

Keywords: financial independence; financial security; public debt 
